\title{
A SUGGESTED PRIVILEGE FOR CONFIDENTIAL COMMUNICATIONS WITH MARRIAGE COUNSELLORS
}

\section{INTRODUCTION}

Recent years have witnessed a large growth in the numbers and activities of marriage counsellors. Although marriage counselling has long been practiced as an informal art by people in all walks of life, only in the past twenty-five years has it achieved stature as a profession. ${ }^{1}$

Marriage counselling's major aim, as the name implies, is to aid spouses in understanding the nature of their marital difficulties. A prime desire is the prevention of divorce, but failing this, the objective is to aid in the adjustment of the partners to that contingency. ${ }^{2}$ Clients' problems may run the gamut from simple personality idiosyncrasies or health complications to infertility, impotence, homosexuality, alcoholism, frigidity and infidelity. ${ }^{3}$ Aside from the relatively minor amount of information which the counsellor might be able to glean by observation, the great majority of his knowledge of the client must come from personal discussion. ${ }^{4}$ The therapeutic value to the client, in fact, springs to a great extent from his opportunity to talk over his problems with a sympathetic listener. ${ }^{5}$ At the same time, he is given the benefit of sharing in the counsellor's broad understanding of the problems and possible solutions of marital difficulties.

It is apparent that much of the information divulged by the client may be highly relevant evidence in subsequent litigation, particularly marital actions. Ordinarily, of course, a person may not testify concerning the substance of statements made to him by another where such evidence is offered to prove the truth of the statements. ${ }^{6}$ But there are many exceptions to the hearsay rule, ${ }^{7}$ including admissions by parties, ${ }^{8}$ witnesses'

1. See Mudd, The Practice of Marriage Counseling 4-8 (1951) (hereinafter cited as MUnD).

2. Johnstone, Marriage Counselling Services in Kansas and Kansas City, Missouri, 3 KAN. L. REv. 116, 117 (1954). "Marriage counselling offers no guarantees. But in many cases it offers more hope of an intelligent, permanent solution to marital problems than either divorce without counselling or reconciliation without counselling." Ibid.

3. Mudv 67.

4. Johnstone, supra note 2 , at 117.

5. See Mudv 178-79. "Remember that in most instances the person seeking help is the one who does the work. He is offered the opportunity ... [of using] the counsellor as an objective sounding board. ... [A]llowed to do this ... in the majority of instances he will be able to change his attitudes and develop new and unused parts of himself." MUDD 40-41.

6. See, e.g., 5 Wigmore, Evidence 2 (3d ed. 1940) (hereinafter cited as WiGMIORE); MCCORMICK, EVIDENCE 460 (1954) (hereinafter cited as MCCORMICK); UNIFORM RULES OF EVIDENCE rule 63.

7. See, e.g., 5 WIGMORE 208-09; UNIFORM RULES OF EVIDENCE rule 63(1)-(31).

8. E.g., UNIFORM RULES OF EvtDENCE rule 63(7). 
declarations against interest, ${ }^{9}$ and declarants' statements offered to show state of mind. ${ }^{10}$ Thus, for example, a statement by the client of past misconduct, either bearing on the validity of the marriage or on the presence of recognized grounds for divorce, would be admissible in a marital action between the spouses. ${ }^{11}$ Similarly, vilification of the spouse might be offered to prove lack of affection. If relevant, the counsellor's testimony as to these statements could also be used in third-party and criminal actions in addition to marital litigation.

Otherwise relevant and admissible statements may be withheld from disclosure, however, if the law recognizes the relationship between the communicants as privileged, ${ }^{12}$ and the statements are made in confidence. At present, the relationships of husband-wife, ${ }^{13}$ attorney-client, ${ }^{14}$ and physician-patient ${ }^{15}$ are generally accorded a privilege, while the penitent's confessions to his priest have received substantial statutory protection. ${ }^{16}$ In addition, there has been pressure exerted by other groups, in most cases unavailing, ${ }^{17}$ for the statutory enactment of privileges for their professions. Included among these are privileges for communications to journalists, accountants, social workers and public officials. ${ }^{18}$ Although the trend of the law is probably toward the narrowing of existing privileges rather than the granting of new ones, ${ }^{10}$ it is, nevertheless, surprising that the profession

9. E.g., id. rule $63(10)$.

10. E.g., id. rule $63(12)$.

11. 8 WIGMORE $64,531$.

12. 8 WIGMORE 106. The legal result of this recognition is that the communiçant can prevent admission of the statements into evidence in a court or in other quasijudicial proceedings. For a general discussion of the privilege for confidential communications, see 8 WIGMIORE, $\$ \S 2285-89$; McCormICK 151-64; Note, Privileged Communications-Some Recent Developments, 5 VAND. L. REv. 590 (1952).

13. It has been stated that the husband-wife privilege derived from the common law. Hopkins v. Grimshaw, 165 U.S. 342 (1897); MCCoRMICK 169-70. It is now recognized by statute in most states. For compiled statutes, see 2 WIGMORE, § 488 . See UNIFORM RULES OF EVIDENCE rule 28 . For the general scope of the privilege, see 8 WIGMORE, §§ 2332-41; MCCORAITCK 168-80.

14. This is the oldest of the recognized privileges. Wigmore states the general principle: "(1) Where legal advice of any kind is sought, (2) from a professional legal advisor in his capacity as such, (3) the communications relating to the purpose, (4) made in confidence, (5) by the client, (6) are at his instance permanently protected, (7) from disclosure by himself or by the legal advisor, (8) except the protection be waived." 8 WIGMORE 558 . The privilege is recognized by statute in many jurisdictions. Ibid. See also UNTFORM RULES OF EVIDENCE rule 26.

15. The physician-patient privilege was not recognized at common law but has been enacted by statute in thirty-one states. MCCORMICK 211. Statutes are collected in 8 WIGMORE, $\S 2380$ n.5. It is embodied in the UNIFORM RULES OF EVIDENCE rule 27 , although in brackets, the explanation for which being the commissioners' doubts as to its advisability. McCormick, Sone High Lights of the Uniform Evidence Rules, 33 Texas L. Rev. 559, 570-71 (1955). See in general Note, The Physician-Patient Privilege, 58 W. Va. L. Rev. 76 (1955) ; VANDERBILr, Minimum Standards of JüdxCial Administration 342-44 (1949).

16. This privilege was not recognized at common law. 8 WIGMoR: 843 . It is now protected by statute in thirty-one states. Id. $\S 2395 \mathrm{n} .1$. It is embodied in the UNIFORM RULES OF EVIDENCE TUle 29.

17. See Note, 5 Vand. L. Rev. 590 (1952); Vanderbilit, Minimum Standards of Judictal Administratton 342-44 (1949).

18. Ibid.

19. Ibid. 
of marriage counselling, which requires a high degree of client confidence for its effective operation, has received substantially no consideration as a possible candidate for this protection.

The question does not appear to have arisen in litigation in this country, ${ }^{20}$ but English cases recognize that communications made by estranged spouses to a third party attempting a reconciliation are privileged, at least in a subsequent divorce proceeding. ${ }^{21}$ Since practitioners of marriage counselling frequently have other professional backgrounds including law, medicine and the ministry, ${ }^{22}$ it is possible that the client could claim the privilege associated with his counsellor's primary profession. Nevertheless, if marriage counselling requires a privilege to be effective, and if there is sufficient benefit to be obtained by the public in encouraging its acceptance, this privilege should extend to all who are qualified to practice its methods.

\section{Protection Afrorded Marriage Counselling Communications by Existing Privileges}

Recent data of the American Association of Marriage Counsellors indicates that forty-eight per cent of its members are doctors and eight and one-half per cent are clergymen. ${ }^{23}$ In addition, a number of lawyers necessarily practice marriage counselling to a limited extent in the course of their general duties. ${ }^{24}$ Since more than half of the marriage counsellors already have a privilege by virtue of their "primary" profession, it might be asked why a special privilege for their counselling services is needed. One answer, of course, is that the remainder of those presently engaged in professionaliy recognized counselling are social workers, sociologists, psychologists and educators, ${ }^{25}$ none of whom have a generally recognized privilege. $^{26}$ Moreover, it is not clear that a doctor, minister, or lawyer who practices marriage counselling can invoke the privilege when he strays from the strict limits of his privileged vocation. Thus it has been sug-

20. Ungar, Privilege and the Marriage Counsellor, 5 BRookLYN BAR. 49, 52

21. Henley v. Henley, [1955] 1 All E.R. 590 (P.D.A.); Broome v. Broome, [1955] 1 All E.R. 201 (P.D.A. 1954) ; Pool v. Pool, [1951] 2 All E.R. 563 (P.D.A.); Mole v. Mole, [1950] 2 All E.R. 328 (C.A.); McTaggart v. McTaggart [1948] 2 All E.R. 754 (C.A.). But see Bostock v. Bostock, [1950] 1 All E.R. 25 (P.D.A. 1949) (apparently overruled by Pool v. Pool, supra).

22. See text at notes 23-24 infra.

23. MUDD 70-71. Other professions represented were as follows: $12 \mathrm{r} / 2 \%$ social workers, $121 / 2 \%$ sociologists, $10 \%$ educators and $81 / 2 \%$ psychologists. The figures cited were for the end of 1950 .

24. Martano, A Psychoanalytic Lawyer Looks at Marriage and Drvorce (1952); Mariano, Legal Therapy in Divorce, 3 Kan. L. Rev. 36, 37-40 (1954).

25. See note 23 supra.

26. Despite some pressure in that direction, there has been no privilege granted for social workers. Psychologists have been granted a privilege by statute in Georgia and Kentucky. No privilege has been found to have been suggested for sociologists or educators. See Note, Privileged Communications-Some Recent Developments, 5 VAND. L. REV. 590 (1952). 
gested that although psychiatrists are doctors, communications to them may not be within the medical privilege in states where licensing acts do not apply to treatment of mental disorders and the privilege-granting statute refers to "licensed physicians." 27 Alternatively, psychotherapy may not be construed as "practicing" medicine. ${ }^{28}$ These arguments apply with additional force to the psychiatrist who practices marriage counselling where there may be no element of mental disorder. ${ }^{29}$ On the other hand, those doctors who are not psychiatrists but gynecologists, urologists or simply general practitioners, ${ }^{30}$ may be deprived of their usual privilege on the grounds that marriage counselling is outside the scope of their medical duties.

The same considerations apply to the lawyer-client and priest-penitent relationships. Unless divorce action had actually been filed or was clearly contemplated, it could be argued with some force that marriage counselling was not within the scope of the lawyer's legal duties. An analogous situation is found in those cases which hold that the lawyer who handles his client's accounting problems may not invoke the privilege for that branch of his activities. ${ }^{31}$ The minister faces the same problems, for his privilege is intended to extend only to confessionals required by the canons of his church. $^{32}$ Information given to clergymen outside the confessional has been held not to be privileged.33

Another impediment to the application of existing privileges to marriage counselling communications is the problem of waiver, that is, the effect of the presence of a third person, in this case the other spouse, on the privilege of confidentiality with the counsellor. Marriage counsellors maintain that there is often value to be had through joint interviews with the spouses. $^{34}$ But in most situations the presence of a third person destroys a privilege on the reasoning that the communication could not have been

27. See Guttmacher \& Weihofen, Privileged Communications Between Psychiatrist and Patient, 28 IND. L. REv. 32, 37 (1952).

28. Guttmacher \& Weihofen, supra note 27 , at 37-39.

29. See text at notes 53-54 infra.

30. A breakdown of the membership of the American Association of Marriage Counsellors in 1950 -showed that of the $48 \%$ who were physicians, only $17 \%$ were psychiatrists, the other classifications being $27 \%$ gynecologists, $2 \%$ urologists and $2 \%$ general medicine. Mudd 70-71.

31. See, e.g., Oleander v. United States, 210 F.2d 795 (9th Cir. 1954); United States v. Chin Lim Mow, 12 F.R.D. 433 (N.D. Cal. 1952); United States v. United Shoe Mach. Corp., 89 F. Supp. 357 (D. Mass. 1950). Cf. MCCormick 184-85.

32. The Uniform Rules of Evidence provide a privilege for "penitential communications." "[P] enitential communication' means a confession of culpable conduct made ... to a priest in the course of discipline or practice of the church. . . "UNIFORM RULES OF EVIDENCE rule 29(1) (c). See also 8 WIGMIORE, \$\$ 2394-96; Regan \& Macartney, Professional Secrecy and Privileged Communications, 2 CATHOLIC LAWXER 3, 14 (1956).

33. E.g., In re Koeller's Estate, 162 Kan. 395, 176 P.2d 544 (1947) ; Johnson v. Commonwealth, $310 \mathrm{Ky} .557,221$ S.W.2d 87 (1949). The latter problem is probably more theoretical than practical since it would be questionable tactics, at least in jury cases, for the attorney to attempt to force a priest to divulge information which he felt had been given in confidence. See Regan \& Macartney, supra note 32, at 14.

34. Johnstone, supra note 2, at 116-17; Mudv 189. 
intended to be confidential. ${ }^{35}$ If two people consult an attorney for their mutual benefit, the communications are confidential as between the communicants and others not a party to the conference, but are not privileged as between themselves. ${ }^{36}$ For example, if spouses confer with an attorney to arrange a contract between themselves neither is allowed to invoke the lawyer-client privilege against the other. ${ }^{37}$

The marriage counselling conference would seem to require a contrary result. If full advantage is to be gained from joint discussions with the counsellor, communications in the conference should be privileged as against all parties thereto. ${ }^{3 S}$ An analogy is perhaps offered by the exclusion from evidence of offers of compromise, which McCormick explains as a privilege in the interests of encouraging settlements. ${ }^{39}$ Nevertheless, as the law stands, waiver is an effective bar.

\section{Should a Marriage Counselling Privilege Be Recognized?}

A convenient framework within which to explore the desirability of a marriage counselling privilege are the four criteria advanced by Wigmore:

"(1) The communications must originate in a confidence that they will not be disclosed; (2) This element of confidentiality must be essential to the full and satisfactory maintenance of the relation between the parties; (3) The relation must be one which in the opinion of the community ought to be sedulously fostered; and (4) The injury that would inure to the relation by the disclosure of the communications must be greater than the benefit thereby gained for the correct disposal of litigation." 40

\section{Do the Statements Arise in Confidence?}

In the case of any professional consultation, it is reasonably clear that the client tacitly assumes that any statement made during the conversation will not be disclosed. This springs not from the nature of the statements but from a general awareness of professional ethics. ${ }^{41}$ Whether statements will be legally recognized as confidential must rest on the usual circumstances and types of information offered in the given professional relation. The inference of confidence is strongest in the priest-penitent relation where the information elicited is required and consists of a wife).

35. See, e.g., McCormick 192 (lawyer-client); 8 WIGMore, § 2336 (husband-

36. MCCoRMick 177.

37. See Tracy v. Tracy, 377 Pa. 420, 105 A.2d 122 (1954). Cf. Knox v. Knox, 222 Minn. 477, 25 N.W.2d 225 (1946).

38. This view has support in the English cases. Pool v. Pool, [1951] 2 All E.R. 563 (P.D.A.) ; Harris v. Harris [1931] Prob. 10. See also O'Brien v. New England Mut. Life Ins. Co., 109 Kan. 138, 142, 197 P.2d 1100 (1921) (dictum); Comment, 34 Mich. L. REV. 875 (1936).

39. MCCoRMICK 158.

40. 8 WIGMORE 531.

41. Cf. Gutrmacher \& Weithofen, Psychiatry and the Law 274 (1952). 
confession. To a somewhat lesser extent this is true of the lawyerclient relation which may involve highly personal data revealed because of impending litigation. The doctor-patient privilege, on the other hand, has been severely criticized as involving physical data rarely kept secret from others. ${ }^{42}$ Moreover, there is generally no thought of litigation which would impart a need for confidence. ${ }^{43}$

The objections to the physician-patient privilege appear to be met in marriage counselling. Like the lawyer, the marriage counsellor in order to be effective must learn a great deal through prolonged discussions. This process requires a thorough exploration into the conduct and attitudes of both parties.4 There is, moreover, a natural reticence to speak of the intimate relations associated with the marriage. This reticence may often be strengthened by the realization, as in the lawyer-client relation, that litigation is not far removed. Thus the person who seeks marriage counselling in all probability has recognized that divorce is often the legal result of an unsatisfactory union. By virtue of the nature of the communications and the circumstances under which they are given, marriage counselling comes close to the legal relationship in its intended confidence.

\section{Is Confidentiality Essential to the Full and Satisfactory Maintenance of the Relation?}

There is general agreement that this criterion is met by the lawyerclient and husband-wife relations. ${ }^{45}$ Once again, however, the physicianpatient relationship has been strongly challenged in that the information required for effective treatment is seldom confidential, ${ }^{\mathbf{4 6}}$ and because people would seek medical aid in the absence of a privilege. ${ }^{47}$

Unlike the doctor who may be able to treat his patient despite the fact that the latter is uncommunicative, the marriage counsellor requires extended discussion with his client. And unlike the lawyer who needs information which his client will probably recognize as having a logical relation to the legal problem, the counsellor must encourage the client to discuss events which the client may deem totally unrelated to his marriage difficulties. In this respect the marriage counsellor's need for information compares with that of a psychiatrist. ${ }^{48}$

42. See, e.g., 8 WIGMORE 812 ; MCCORMICK 222.

43. An exception arises in those cases in which the patient intends to sue for personal injuries. These latter situations are justifiably excluded from privilege under the terms of most statutes. See, e.g., UNIFORM RULEs OF EvIDENCE rule 27(4); CAL. CoDE, Civ. Proc. Annotations \$ 1881 (West 1955); 8. Wigmore 812; McCormick 222. But McCormick states that courts have been reluctant to make this exception in the absence of statutory demands. McCorMIck 220.

44. Johnstone, supra note 2, at 117. Cf. Mud 203-08.

45. But see McCormick 179: “. . the probable benefits of the rule of privilege in encouraging marital confidences and wedded harmony, is at best doubtful and marginal."

46. 8 WIGMORE $\$ 11$.

47. Ibid.

48. Both disciplines require extended discussion not only in order to get at the root of the difficulty, but also as a part of the therapy itself. See text and notes at notes 4-5 supra; text and notes at notes 49-57 infra. 
Of the psychiatrist-patient relation it has been said that "the peculiarly close relationship of trust and confidence required in psychotherapy makes the situation a special one, not necessarily governed by the same considerations as ordinary doctor-patient relations." 49 This difference has been recognized in at least one case where a privilege was granted for psychiatrists in the absence of a privilege for doctors in general. ${ }^{50}$ In addition, two states have enacted statutes giving a privilege to psychologists. ${ }^{51}$ Marriage counsellors make use primarily of the knowledge. and techniques of the behavioral sciences, particularly psychiatry and psychology. ${ }^{52}$ The essential difference between counselling and psychiatry lies in the complexity of the latter's psychotherapeutic techniques. ${ }^{53}$ Thus, the emotional overtones of a marriage relation may be disturbed, but they are not necessarily the same conflicts which produce neurosis. ${ }^{54}$ The marriage counsellor carries on his client discussions at the conscious level and is primarily interested in the inter-personal relationship between the spouses. ${ }^{55}$ If the root of the difficulty is identified as a neurosis of one of the partners, reference is usually made to a psychiatrist. Thus the counsellor does not require the confidence of the client to probe into his subconscious thoughts, ${ }^{56}$ and in this respect his need for a privilege is not so great as the psychiatrist's. ${ }^{57}$ On the other hand, it has been indicated that in a large percentage of the cases referred to counselling, the more emotionally mature spouse has instigated the relationship and the real difficulty lies with the other partner. ${ }^{58}$ If the marriage is to be helped, the counsellor must do a thorough job of selling himself to the spouse who did not originate the relation. The element of complete confidence would appear essential in this situation. So strong is the need that the counsellor may feel it imperative to volunteer advance assurance to the client that strict confidence will be observed. ${ }^{59}$ Furthermore, the a priori possibility of litigation in the divorce courts makes the counsellor's information gathering process perhaps more difficult than the psychiatrist's; in this respect it is closer to the attorney-client relationship.

49. Gutmmacher \& Weinofen, Psychiatry and the Law 270 (1952).

50. Binder v. Ruvell, Civil No. 25C2535, Cook Co. Circuit Ct. (I1l.) June 24, 1952; Note, Confidential Communications to a Psychotherapist: $A$ New Testimonial Privilege, 47 Nw. U.L. REv. 384 (1952). See also Taylor v. United States, 222 F.2d 399 (D.C. Cir. 1955), in which testimony of a state employed psychiatrist was held privileged under the medical statute, but the language of the court emphasized the special need for a privilege in the psychotherapy field. 4 KAN. L. Rev. 597, 54 Mich. L. REv. 423 (1956).

51. Kentucky and Georgia. See Ga. Code Anv. § 84-3118 (1955) ; Kx. Rev. Stat. $\$ 319.100$ (1953).

52. Johnstone, supra note 2 , at 116.

53. See Mund 203-08.

54. Ibid.

55. Ibid.

56. Ibid.

57. See Gutrimacher \& Weihofen. Psychiatry and the Law 272, 279 (1952).

58. Mudd, The Social Worker's Function in Divorce Proceedings, 18 LAw \& CoNTEMP. PROB. 66, 70 (1954).

59. Mudd 39, 182-83. 


\section{Is the Relation One Which in the Opinion of the Community Ought To Be Sedulously Fostered?}

There is universal agreement that all the professional relationships which are generally privileged at present should be "sedulously fostered." Formal marriage counselling, on the other hand, is new and for the most part untried. It is an example of activities which were at one time handled within the family but which now, due largely to the increased specialization of our economy, are being shared with the community. ${ }^{60}$ It has been described as a community facility which has developed to promote personal and marital adjustment. ${ }^{61}$ Whether or not as a profession it should receive a privilege, however, depends in part on the community's judgment of its ability to fulfill a need. The divorce rate furnishes the need if marriage counselling can prove effective in lowering it.

\section{Divorce-The Problem}

At the present time there is one divorce for approximately every four marriages. ${ }^{62}$ In 1946, the high level year, there were 610,000; in recent years the number has been consistently close to 400,000 but the divorce rate has been increasing. ${ }^{63}$ It has been estimated that divorce cases make up approximately one-half of all civil suits filed in the courts of first instance. ${ }^{64}$ Unfortunately, marriage problems, unlike medical problems, necessarily involve at least two people, and in most cases involve the futures of minor children. For a large segment of the population, therefore, a divorce can create an economic as well as a social situation having impact upon the remainder of the community. Indeed, it has been suggested that society has an interest in every marriage which is paramount to the interests of the parties themselves. ${ }^{65}$ The national awareness of the problem is reflected in courses in marital preparation and relations given by colleges, the dissemination of marital literature and the development of marriage counselling centers in forty states. ${ }^{66}$

60. MUdD 4.

61. Ibid.

62. New York Wordd Telegram, The Wored Almanac 375 (1957).

63. The divorce rate steadily increased from 1890 to 1946 . Since then, the number of divorces per unit population has decreased. The number of divorces is tied very closely to the marriage rate, i.e., a year of many marriages is usually a year of many divorces, 7 ENCYC. Britranica 460-61 (1954 ed.). However, the ratio of divorces to marriages has been increasing. NEW YORK WORLD TELEGRAM, WorLd AlMANAC 375 (1957). See Chute, Divorce and the Family Court, 18 Law \& Contemp. Prob. 49 (1954); Ellzey, Marriage or Divorce, 22 U. KAN. CITY L. REv. 9 (1953).

64. Johnstone, Divorce Dismissals: A Field Study, 1 KAN. L. REv. 245 (1953). See also VIRTuE, FAMILX Courrs (1956); Alexander, Family Cases are DifferentWhy not Family Courts?, 3 KaN. L. Rev. 26, 32 (1954).

65. MacKensie, Spiritual Values and the Family Court, 18 LAW \& CoNTEMP. Prob. 20, 22 (1953). See also Chute, supra note 63; Sayre, Divorce for the Untworthy, 18 LAW \& CoNTEMP. PROB. 26, 32 (1953).

66. Mudv 6, 11 ; Ellzey, supra note 63, at 16. 
The establishment of family courts, ${ }^{67}$ perhaps the most significant divorce reform currently being advocated, ${ }^{68}$ has revealed an important area within which marriage counselling can be useful, despite the fact that divorce is being considered by the parties.

In a large percentage of cases in a recent study, filing of suit for divorce was done for the admitted purpose of bringing the recalcitrant spouse "into line." 69 Although statistics are meagre, this hypothesis has been strengthened by the fact that in many cases reconciliation results if there is a delay in the proceedings. ${ }^{70}$ Despite the fact that less than ten per cent of divorce actions are contested, ${ }^{71}$ there is a high percentage of dismissals. ${ }^{72}$ These figures, though far from conclusive, suggest that a substantial number of people with marital difficulties do not "want" divorce even after filing. ${ }^{73}$ Consequently, the dismissal rate might be significantly higher were reconciliation services available.

Despite the growing number of family courts, they are by no means a full solution to the divorce problem. ${ }^{74}$ Since few courts have adequate programs for reconciliation at the present time ${ }^{75}$ the full burden of exploring the possibility of saving a marriage usually falls on the lawyer. Unfortunately, the lawyer is generally ill-equipped to handle the psychological and emotional issues which blend with the legal issues in a family breakdown. ${ }^{76}$ The fact that there appears to be an opportunity for the beneficial exercise of the counsellor's special knowledge, however, does not necessarily mean that he can in fact save a large number of otherwise hopeless marriages. Until there are statistics available to indicate a comparison between the divorce rate with and without counselling, it would seem premature to grant a privilege to an unproved profession. But until family

67. A family court is an expanded juvenile court having the two-fold purpose of guidance and adjudication. Johnstone, Family Courts, 22 U. KAN. CIrY I. REv. 18 (1953). The most important feature of this broadened jurisdiction is considered to be the presence of reconciliation services and general marriage counselling. Johnstone, supra at 19. (1953).

68. Johnstone, Divorce Dismissals: A Field Study, 1 Kan. L. Rev. 245, 255

69. Johnstone, supra note 68 , at 254.

70. MacKensie, supra note 65 , at 24 .

71. Pilpel \& Zavin, Separation Agreements: Their Function and Future, $18 \mathrm{LAw}$ \& Contemp. Prob. 33, 34 (1953) ; Sayre, supra note 65, at 27.

72. Johnstone, supra note 68 , at 245.

73. Johnstone, supra note 68, at 255. See also MacKensie, supra note 65 , at 24.

74. The nearest approach has probably been achieved in the Circuit Court of Toledo, Ohio, where two full-time marriage counsellors are available at no charge in cases referred by lawyers. Chute, supra note 65 , at 53 . Other efforts have culminated in legislation in several states requiring reports by probation officers whenever the custody of minor children is involved. Chute, supra note 65 , at 60 ; Alexander, supra note 64 , at 31-32. Some difficulty has been experienced with constitutional issues, see, e.g., Christianson v. Connell, 2 I11. 2d 332, 118 N.E.2d 262 (1954), but the main objection to family courts has been the expense involved and the delays necessarily incident to a proper investigation of case backgrounds. Johnstone, supra note 68 , at 20 . In addition, there is a natural reticence on the part of lawyers who feel that the social worker and counsellor are usurping the legal function. Ibid.

75. Pilpel \& Zavin, supra note 71, at 37.

76. Pilpel \& Zavin, supra note 71 , at 36,38 . See also Mariano, Legal Therapy in Divorce, 3 Kan. L. Rev. 36, 37-40 (1954). 
courts are able to assume the burden, perhaps a compromise solution would be to grant counsellors a privilege whenever there is a reference by an attorney. If counselling proves to avert divorce in a substantial percentage of the cases it should certainly be "sedulously fostered"; until then, this criterion seems the weak link in a claim for a counselling privilege.

\section{Is the Injury That Would Inure to the Relation by the Disclosure of the Commnnications Greater Than the Benefit Thereby Gained for the Correct Disposal of Litigation?}

It is apparent that the injury to the correct.disposal of litigation will be proportional to the amount of evidence excluded, which in turn is related, although not necessarily in direct proportion, to the scope of the privilege. To be effective, a counselling privilege must at least enable the communicating spouse to prevent disclosure of his confidential statement by either the other spouse or the marriage counsellor. It may even be desirable to permit the noncommunicating spouse to bar introduction of confidential statements by the communicating spouse if admission would require the introduction of otherwise privileged statements in rebuttal. ${ }^{77}$ As to the types of actions in which the privilege may be exercised, the ininimum necessary privilege would encompass marital actions between the spouses. At the other extreme, the privilege could be extended to include all actions, whether between the spouses or involving third parties. The argument for a limited privilege, aside from the fact that less evidence would be excluded overall, is that the spouses at the time of the conference are concerned only with possible marital litigation, hence require only an assurance that their statements will not be admissible in such actions; and if the privilege is limited to such actions, its primary impact will be upon the spouses rather than upon third parties.

The case for the broad privilege rests on the assumption that anything short of a complete assurance by the marriage counsellor of confidentiality will make the client reticent to reveal the amount of information necessary for effective counselling. Moreover, statements made in counselling conferences will generally be relevant only to subsequent marital litigation. ${ }^{8}$ The frequency with which statements would be relevant in other types of actions is small, hence little additional evidence is lost by the broader privilege. Balancing this against the asserted gain to the counsellor from a full assurance of confidentiality, the broader privilege seems desirable.

77. McTaggart v. McTaggart, [1948] 2 All E.R. 754, 755 (C.A.) (dictum); Walker v. Wilsher, [1889] 23 Q.B. 335 (on issue of awarding costs, defendant's evidence that prior to suit he offered plaintiff the same sum as his judgment held privileged). See also Withont Prejudice, 92 SoL. J. 653 (1948). There may be value in guaranteeing that a statement cannot be introduced in evidence if either the communicant or noncommunicant should object. Otherwise, the parties might be tempted to color their statemets in the hopes of later introduction, which in turn would hamper the counselling process. See note 80 infra.

78. All the English cases dealing with this privilege have been divorce proceedings. See cases cited at note 21 supra. 
In determining whether any privilege should be granted, the focus should be on marital actions. Although the privilege withdraws one source of proof, other sources are available in many of the situations involved. For example, if the claimant of the privilege is a party in a divorce action, the other spouse can testify from personal knowledge of conduct such as cruelty, failure to support or neglect. On the other hand, there may be lack of adequate evidence of adultery, or in annulment actions, of facts bearing on the validity of the marriage. Similarly, conversations relevant to show defendant's state of mind, such as lack of rationality or animosity toward the spouse, may be otherwise unobtainable and lost if a privilege is granted. Such grounds for divorce or annulment as a prior subsisting marriage or a previous commitment for mental disorder may also be outside the present spouse's knowledge. If these grounds are suspected, however, they should be readily proved from public records or by putting the defendant on the stand.

The balance against the injury to the proper disposal of litigation is the benefit to the relationship of counsellor and client to be gained from the existence of the privilege. This benefit inures to society as well if the counsellor is able either to prevent divorce or to reconcile the parties to that eventuality. ${ }^{79}$

Thus, if divorce is avoided, the testimony should be privileged under the same rationale which excludes offers of compromise in the interests of preventing litigation. If divorce is unavoidable, then the public has benefited from the correct disposal of the marital problem by eliminating the adversary aspect of the case.

\section{To Whom Should the Privilege Extend?}

The question remains as to who should qualify as a marriage counsellor for purposes of a privilege. The privilege contemplated would extend to all communications made to a counsellor in order to avoid marital difficulties as well as to solve problems which have already arisen. The prevalence of informal marital advice given during conversations when other information might be revealed could permit the frequent claim of privilege. It is apparent that the possibility of abuse is too great to allow a privilege to extend to informal counselling. ${ }^{80}$

79. It would seem reasonable that in a large percentage of cases intelligent counselling could at least result in diminishing contested divorces by educating both parties to that course if it is the most desirable alternative. This might well result in fuller voluntary disclosures by those concerned, thereby eliminating the adversary aspect of marital cases.

80. The privilege of the English cases is not limited to communications to persons meeting formal standards of professional competence. McTaggart v. McTaggart, [1948] 2 All E.R. 754 (C.A.) (probation officer of magistrate's court) ; Pool v. Pool, [1951] 2 All E.R. 563 (P.D.A.) (attorney) ; Broome v. Broome, [1955] 1 Ail E.R. 201 (P.D.A.) (representative of servicemen's association); Henley v. Henley, [1955] 1 All E.R. 590 (P.D.A.) (country vicar). This recognition is an outgrowth of the protection that English courts have given to all communications made "without prejudice" during the course of negotiations where litigation is pending or likely. Hoghton v. Hoghton, 15 Beav. 278, 315, 321 (1852); La Roche v. Armstrong, [1922] 1 K.B. 
Determination of who qualifies as a counsellor for purposes of a privilege is made difficult by the absence of formal standards to determine competence. At the present time marriage counselling is not licensed as a profession; in fact, there is considerable controversy in the profession itself as to whether licensing would be desirable. 81 A satisfactory compromise would appear to be to require strict compliance with qualifications for membership in a recognized group such as the American Association of Marriage Counsellors. These usually include a graduate degree in one of the social sciences or a professional degree with a minor in social science, and commonly three or more years of experience in field work. ${ }^{82}$ Indeed, it might be advantageous to require membership in a recognized association in addition to the meeting of certain minimum standards of competence set by that association. The association could thus act as a policing agency to protect the ethics of the practice in the absence of licensing requirements.

An additional problem is presented by the inter-professional activities of many marriage counsellors. Thus, many who practice do so not as members of counselling agencies or even as free lance full-time counsellors. Figures of the American Association of Marriage Counsellors indicate that fifty-six per cent of the membership carry on counselling as a part of their day-to-day practice in another field, while only six per cent are privately engaged in full time counselling. ${ }^{83}$ The counsellor's privilege should extend only to activities which he performs in that capacity. This poses the question of when counselling begins and the other activity breaks off.

485 (cited in McTaggart v. McTaggart, supra). One explanation is that the privilege furthers the desirable aim of settling disputes by protecting statements made during negotiations. When divorce is involved there is an additional rationale. "[I]n matrimonial disputes, the State is also an interested party and is more interested in reconciliation than in divorce, and if the rule as to privilege tends to promote the prospects of reconciliation, I think it ought to be applied. ..." Mole v. Mole, [1950] 2 A1l E.R. 328,329 (C.A.). If the third party were ". . compelled to give evidence as to what was said in the course of negotiations, it would mean that, when he attempted reconciliation, he would not be told the truth, or, at all events not the whole truth. The parties would have at the back of their minds the thought that whatever they said might be given in evidence against them or for them, and would colour their statements accordingly. There is no chance of reconciliation unless the parties are able to talk with frankness. . ." McTaggart v. McTaggart, supra at 756. Since the primary emphasis of the English privilege is avoidance of divorce, a communication cannot qualify unless "litigation is imminent." McTaggart v. McTaggart, sitpra at 755, or there is at least an "occasion for reconciliation." Broome v. Broome, sttpra at 205. In addition, the third party must have been acting in his "capacity as conciliator." Id. at 207, and there must have been a "tacit understanding that the communications were without prejudice. . " Pool v. Pool, supra at 566 . Although this privilege appears liberal in protecting ail confidential communications made with a view toward reconciliation, it fails to protect communications made to avoid the difficulties which give rise to a need for reconciliation. Protection of these latter statements compels a requirement that the counsellor meet some professional standard of competence.

81. This springs in large measure from a fear on the part of licensed physicians that others, through marriage counselling, may be placed in a position to do work for which they are not qualified and by which they could do considerable harm. Compare Stokes, Legal Status of the Marriage Coninsellor, 13 Marriage \& Family Living 113 (1951), with Ellis, Legal Status of the Marriage Counsellor, 13 Marriage \& Family Living 116 (1951).

82. MudD 64-66.

83. MUDD 71. 
An analogous problem arises when, in the course of marriage counselling the counsellor refers the client to a specialist for advanced treatment.

In reference cases the privilege might continue at least when the treatment is necessary to the marriage therapy, and the counsellor maintains some administrative supervision over the client's case. This would have the effect of encouraging reference cases when the counsellor himself is unqualified to handle that aspect of the treatment.

\section{ConcLUSION}

Although the trend of the law has been to narrow privileges for confidential communications, it has been suggested that marriage counselling may be deserving of consideration for this legal protection. The benefits to be obtained from its use may prove considerable in view of the extensive social and economic problems created by the large divorce rate. The therapy which is used requires that the communications be held in confidence. Privileges currently enjoyed by counsellors arising out of their professions as doctors, lawyers and clergymen appear inadequate to protect the counselling function and raise additional problems of waiver when there is joint therapy. On the other hand, the beneficial effect which counselling may have on the divorce problem has not been fully evaluated and it would appear unwise to grant a privilege to a new profession without a guarantee as to its effectiveness. A suggested orientation is to encourage lawyers to make references to counsellors and to allow a privilege in this limited case. This could have the result of elevating the prestige of the profession in the public's eyes, and at the same time encouraging the person with marital difficulties to derive the utmost benefit by a free communication in the knowledge that his confidences cannot be divulged.

D. A., III 